\title{
Acceptability of ice cream products of red fruit (Pandanus conoideus lamk) with sago flour subtitution (Metroxylon sagu rottb)
}

\author{
Radeny Ramdany ${ }^{* 1}$, La Supu ${ }^{2}$, Fatimah N. Pulukadang ${ }^{3}$ \\ ${ }^{1,2,3}$ Bagian Gizi, Politeknik Kesehatan Sorong, Papua Barat
}

DOI: $10.24252 /$ al-sihah.v12i2.15908

Received: 13 September 2020 / In Reviewed: 16 September 2020/ Accepted: 24 September 2020 / Available online: 28 September 2020 (C) The Authors 2020. This is an open access article under the CC BY-NC-SA 4.0 license

\begin{abstract}
Ice cream is a frozen food product that is processed through a combination of freezing processes in a mixture of various ingredients consisting of milk or milk products, sweeteners, emulsifiers, stabilizers, and flavor enhancers. The addition of ice cream with local Papuan food modifications, namely red fruit and sago flour, is expected to add nutrition and become a new innovation for local ice cream products in the City of Sorong, West Papua. The purpose of this study was to determine the acceptability of the red fruit ice cream product with sago flour substitution. The research design used was experimental research. The samples used as objects were ice cream products with the addition of red fruit juice and sago flour with 3 variations (S00, S20, S30). This study used a fairly trained panel of 25 people. The independent variable is the variety of ice cream with red fruit juice and sago flour substitution and the dependent variable is acceptance (taste, aroma, color, texture). The instrument used in this study was the hedonic test form. Acceptability analysis using the Friedman Test. The results showed that there were significant differences in taste (p-value 0.006), aroma (p-value 0.006), color (p-value 0.001), and texture (p-value 0.010) of ice cream products with the addition of red fruit juice and Sago flour. This study found that there were differences in the acceptance of ice cream with variations in the substitution of sago flour and red fruit.
\end{abstract}

Keyword: acceptability; ice cream; red fruit; sagu floor

\begin{abstract}
ABSTRAK
Es krim merupakan produk makanan beku yang diolah melalui kombinasi proses pembekuan pada campuran berbagai bahan yang terdiri dari susu atau produk susu, bahan pemanis, bahan pengemulsi, bahan penstabil, serta penambah cita rasa. Penambahan es krim dengan modifikasi pangan lokal Papua yaitu buah merah dan tepung sagu diharapkan dapat menambah nutrisi serta menjadi inovasi baru dari produk es krim lokal di Kota Sorong, Papua Barat. Tujuan dari penelitian ini adalah untuk mengetahui daya terima dari produk es krim buah merah dengan substitusi tepung sagu. Desain Penelitian yang digunakan yaitu penelitian eksperimen. Sampel yang digunakan sebagai objek adalah produk es krim dengan penambahan sari buah merah dan tepung sagu dengan 3 variasi (S00, S20, S30). Penelitian ini menggunakan panelis agak terlatih berjumlah 25 orang. Variabel independen yaitu variasi es krim dengan substitusi sari buah merah dan tepung sagu dan variabel dependen adalah daya terima (rasa, aroma, warna, tekstur). Instrumen yang digunakan dalam penelitian ini yaitu formulir uji hedonic. Analisis daya terima dengan uji friedman . Hasil penelitian menunjukkan bahwa terdapat perbedaan yang signifikan terhadap rasa ( $\mathrm{p}$-value 0.006 ), aroma ( $\mathrm{p}$-value 0.006 ), warna ( $\mathrm{p}$-value 0.001$)$ dan tekstur ( $\mathrm{p}$-value 0.010 ) dari produk es krim dengan penambahan sari buah merah dan tepung sagu. Penelitian ini menemukan bahwa terdapat perbedaan daya terima es krim dengan variasi substitusi tepung sagu dan buah merah.
\end{abstract}

Kata kunci: buah merah; daya tolak; es krim; tepung sagu

*Alamat Korespondensi:

Jl. Basuki Rahmat Km. 11 Kota Sorong, Papua Barat

Email: radeny_ramdany@yahoo.com
ISSN-P : 2086-2040

ISSN-E : 2548-5334

Volume 12, Nomor 2, Juli-Desember 2020 


\section{PENDAHULUAN}

Es krim adalah salah satu produk susu yang aman dan bergizi serta menjadi produk beku yang banyak digemari dan dikonsumsi di seluruh dunia (Tewati et al., 2019). Bahan yang dimanfaatkan dalam proses pembuatan biasanya adalah kombinasi susu dengan satu atau lebih bahan tambahan lainnya dengan atau tanpa stabilizer (Ridawati \& Alsuhendra, 2015). Banyak orang yang memilih es krim yang memiliki nilai kandungan gizi yang tinggi dan memberikan dampak kesehatan masyarakat. Rasa suka yang mendorong orang untuk mengonsumsi es krim di dasarkan pada nilai kandungan nutrisi di dalamnya (Bullock et al., 2020). Es krim memiliki potensi yang baik untuk digunakan sebagai pembawa pro biotik karena komposisinya serta rasanya yang enak dan teksturnya yang menarik. Selain itu, pro biotik mampu bertahan dalam waktu yang lama dalam keadaan beku seperti matriks es krim yang mencakup kandungan nutrisi seperti protein susu, lemak, dan laktosa (Cruz et al., 2009). Es krim juga mengandung zat gizi lain yaitu karbohidrat serta lemak, dimana kedua zat ini merupakan faktor yang membuat es krim digemari (Hartatie, 2011).

Buah Merah (Pandanus conoideus Lam) merupakan tanaman endemis yang dapat tumbuh di hampir seluruh wilayah Papua, mulai dari dataran rendah hingga dataran tinggi. Buah Merah (Pandanus conoideus Lam) termasuk dalam family Pandanus, karena tanaman ini termasuk keluarga pandan dengan pohon yang mirip dengan pandan, namun ketinggiannya hanya mencapai 16 meter dengan tinggi tanaman batang bebas cabang sendiri setinggi 5-8 m yang diperkokoh akar-akar tunjang pada batang sebelah bawah.

Buah merah (Pandanus conoideus Lamk) merupakan makanan khas Papua yang telah dimanfaatkan untuk mengobati berbagai macam penyakit seperti kanker (Nuringtyas et al., 2014), preklamsia (Sugiritama et al., 2016), hepatitis (Felle et al., 2016), sirosis hati (Sumarsono \& Susilowati, 2016), diabetes melitus (Roreng et al., 2014), dan sinusitis (Popkov et al., 2001).

Buah merah (Pandanus Conoideus Lamk) Buah merah memiliki aktivitas sebagai antioksidan (Wabula et al., 2019) dan mempunyai kandungan kimia didalamnya yang merupakan zat gizi penting untuk ketahanan tubuh seperti beta karotin (Tang'nga, 2019), tokoferol/vitamin E (Sarungallo et al., 2019), asam linolenat, asam stearat, asam oleat, serta asam palmitat (Schirra et al., 2020). Beta-karotin dan tokoferol diketahui sebagai senyawa yang menghasilkan antioksidan (Jamshidi, 2018). Antioksidan bermanfaat dalam mencegah paparan radikal bebas serta mencegah terjadinya proses oksidasi dalam sistem yang memiliki tekanan oksigen rendah 
(Zulaikhah, 2017). Senyawa beta-karotin juga memiliki kandungan vitamin A yang tinggi (Nzamwita et al., 2017).

Sagu (Metroxylon Sagu Rottb) adalah salah satu alternatif penganekaragaman dalam pembuatan es krim. Sagu yang digunakan dalam pembuatan es krim akan menjadi stabilisator, pencegah kristalisasi, meningkatkan kekentalan, memperbaiki tekstur serta sebagai pengikat (Putri, 2015). Pati dapat bergelatinasi dan berperan dalam pembentukan es krim (Egharevba, 2019), dapat menggantikan fungsi dari CMC (carboxil metil celullose) sebagai bahan stabilizator kimiawi (Manzoor \& Ahmed, 2017). Pati mempunyai kelebihan dalam menyerap air, di mana salah satu sifat dari pati sama seperti CMC yaitu dapat mengikat air (Witono et al., 2014). Sagu dapat menghambat terjadinya proses pelelehan es krim karena sifat dari pati yang kaya gelatin (Metaragakusuma et al, 2016).

Sagu memiliki kandungan air 13,51$17,37 \%$, kadar protein $0,11-0,27 \%$, lemak 0,65-0,87\%, serat $0,39-1,45 \%$, karbohidrat $81,07-83 \%$, pati $70,25-72,61 \%$, amilosa $23,9526,59 \%$ dan amilopektin 43,69-48,4\% (Liestianty et al., 2016).

Dengan berbagai manfaat yang dimiliki oleh buah merah dan sagu tersebut maka penelitian ini perlu untuk mengetahui bagaimana daya terima produk es krim buah merah dengan substitusi tepung sagu.

\section{METODE PENELITIAN}

Penelitian ini menggunakan jenis penelitian eksperimen dengan rancangan acak lengkap dengan 3 variasi sampel es krim, substitusi tepung sagu, dan sari buah merah : S00 (20:0), S20 (20:20) dan S30 (20:30). Penelitian dilakukan pada bulan April 2020. Pengujian daya terima (uji hedonik) menggunakan panelis yang telah diberikan bimbingan yaitu mahasiswa jurusan gizi Politeknik Kesehatan Sorong sebanyak 25 orang.

Variabel bebas meliputi variasi substitusi tepung sagu dan sari buah merah yang diukur dengan satuan gram pada es krim. Sedangkan variabel terikat meliputi daya terima (warna, rasa, aroma dan tekstur). Peralatan yang digunakan dalam pembuatan es krim meliputi: timbangan digital, kom adonan, hand mixer, spatula, freezer, saringan, kompor, gelas ukur, stopwatch, sauce pan, toples tupperware, sendok takar, cup es krim 50 gram dan sendok es krim. sedangkan bahan yang digunakan yaitu: susu full cream, gula pasir, susu kental manis, sari buah merah, tepung sagu, garam, skm, pengemulsi (sp) dan vanili ekstrak.

Pembuatan es krim pada penelitian ini dibuat dengan berbahan dasar susu full cream dengan penambahan tepung sagu kemudian dicampurkan dengan sari buah merah, susu kental manis, pengemulsi (SP), 
vanili ekstrak, gula pasir dan garam. Susu full cream, tepung sagu, susu kental manis, gula pasir dan garam dicampurkan lalu dihangatkan hingga adonan es krim tercampur rata dan mengental. Kemudian adonan
S30 dengan nilai 1.58. Berdasarkan hasil uji statistik friedman, diketahui P-Value 0.006 $<0.05$ yang menunjukkan bahwa terdapat perbedaan rasa es krim yang signifikan dari semua formula teruji.

Tabel 1. Distribusi Karakteristik Responden

\begin{tabular}{|c|c|c|c|c|c|c|c|c|}
\hline \multirow{3}{*}{ Sampel } & \multicolumn{8}{|c|}{ Variabel } \\
\hline & \multicolumn{2}{|c|}{$\begin{array}{c}\text { Tingkat Kesukaan } \\
\text { Rasa }\end{array}$} & \multicolumn{2}{|c|}{$\begin{array}{c}\text { Tingkat Kesukaan } \\
\text { Aroma }\end{array}$} & \multicolumn{2}{|c|}{$\begin{array}{c}\text { Tingkat Kesukaan } \\
\text { Warna }\end{array}$} & \multicolumn{2}{|c|}{$\begin{array}{c}\text { Tingkat Kesukaan } \\
\text { Tekstur }\end{array}$} \\
\hline & $\begin{array}{l}\text { Mean } \\
\text { Rank }\end{array}$ & P-Value & $\begin{array}{l}\text { Mean } \\
\text { Rank }\end{array}$ & P-Value & $\begin{array}{l}\text { Mean } \\
\text { Rank }\end{array}$ & P-Value & $\begin{array}{l}\text { Mean } \\
\text { Rank }\end{array}$ & P-Value \\
\hline $\begin{array}{l}\text { Sampel } \\
\text { S00 }\end{array}$ & 2.06 & & 1.8 & & 1.5 & & 1.62 & \\
\hline $\begin{array}{l}\text { Sampel } \\
\text { S20 }\end{array}$ & 2.36 & 0.006 & 2.48 & 0.006 & 2.36 & 0.001 & 2.26 & 0.01 \\
\hline $\begin{array}{l}\text { Sampel } \\
\text { S30 }\end{array}$ & 1.58 & & 1.72 & & 2.14 & & 2.12 & \\
\hline
\end{tabular}

Sumber: Data Primer, 2020

dibekukan \pm 5-6 jam. Adonan dihaluskan dengan menggunakan -mixer -hingga tekstur agak lembut, setelah itu pengemulsi (SP), vanili ekstrak dan sari buah merah dicampurkan ke dalam adonan, kemudian dihaluskan kembali dengan mixer dan dibekukan kembali. Teknik pengumpulan data dilakukan dengan cara membagikan formulir uji hedonik kepada panelis. Data hasil penelitian yang diperoleh dianalisis menggunakan uji friedman .

\section{HASIL PENELITIAN}

Berdasarkan gambar 1 diketahui bahwa yang memiliki mean rank tertinggi yaitu sampel S20 dengan nilai 2.36, sedangkan mean rank terendah diperoleh pada sampel
Berdasarkan gambar 1 diketahui bahwa yang memiliki mean rank tertinggi yaitu sampel S20dengan nilai 2.48, sedangkan mean rank terendah diperoleh pada sampel S30 dengan nilai 1.72. Berdasarkan hasil uji statistik friedman, diketahui P-Value 0.006 $<0.05$ yang menunjukkan bahwa terdapat perbedaan rasa es krim yang signifikan dari semua formula teruji.

Berdasarkan gambar 1 diketahui bahwa yang memiliki mean rank tertinggi yaitu sampel S20 dengan nilai 2.36, sedangkan mean rank terendah diperoleh pada sampel S30 dengan nilai 1.50. Berdasarkan hasil uji statistik friedman, diketahui P-Value 0.001 $<0.05$ yang menunjukkan bahwa terdapat perbedaan warna es krim yang signifikan 
dari semua formula teruji.

Berdasarkan gambar 1 diketahui bahwa yang memiliki mean rank tertinggi yaitu sampel S20dengan nilai 2.26, sedangkan mean rank terendah diperoleh pada sampel S00 dengan nilai 1.62. Berdasarkan tabel 1 menunjukkan hasil uji statistik friedman, diketahui $p$-value $0.010<0.05$ yang menunjukkan bahwa terdapat perbedaan tekstur es krim yang signifikan dari semua formula teruji.

\section{PEMBAHASAN}

Buah merah yang berasal dari tanah Papua sangat bermanfaat sebagai bahan substitusi pangan. Hasil penelitian Sandhiutami \& Indrayani (2012) menunjukkan bahwa kandungan buah merah memiliki antioksidan yang merupakan senyawa yang memiliki kemampuan untuk menghambat reaksi radikal bebas dalam tubuh manusia. Selain itu Sarungallo et al. (2015) juga menemukan bahwa buah merah mengandung banyak ragam vitamin, asam lemak, termasuk $\alpha$-caroten dan $\beta$ caroten. Dari segi pengobatan alternatif, di samping bermanfaat sebagai anti bakteri pada mulut (Darmayanti et al., 2020), buah merah juga bermanfaat sebagai anti oksidan untuk mengobati penyakit malaria (Triajayanti \& Oktarlina, 2017).

Rasa merupakan atribut sensoris yang tidak dapat digunakan dari keseluruhan cita rasa produk pangan. Rasa berperan sangat penting dalam cita rasa pangan. Berdasarkan hasil uji statistik friedman terhadap frekuensi tingkat kesukaan rasa formulasi es krim, diketahui sebanyak 3 $(12 \%)$ panelis sangat menyukai rasa es krim pada sampel S20 dengan komposisi penambahan sari buah merah sebanyak 20 gram. Dan sebanyak 6 (24\%) panelis tidak menyukai rasa es krim pada sampel S30 dengan penambahan sari buah merah sebanyak 30 gram.

Dilihat dari nilai tingkat kesukaan rasa, nilai rata-rata terbesar yaitu pada formula es krim S20 dengan nilai rata-rata 2.36. Seperti pada penjelasan sebelumnya, maka dapat diketahui bahwa penambahan sari buah merah yang berlebih dapat mempengaruhi tingkat kesukaan terhadap rasa dari formula es krim tersebut.

Aroma merupakan hasil dari uap proses pengolahan makanan, uap ini dihasilkan dari makanan yang telah diolah. Setiap bahan memiliki aroma yang berbeda, proses dan metode memasak akan mempengaruhi hasil dari aroma yang akan tercium.

Berdasarkan hasil uji statistik friedman terhadap frekuensi tingkat kesukaan aroma formulasi es krim, diketahui sebanyak $6(24 \%)$ panelis sangat menyukai aroma es krim pada sampel S20 dengan komposisi penambahan sari buah 
merah sebanyak 20 gram. Dan sebanyak 5 (20\%) panelis tidak menyukai aroma es krim pada sampel S30 dengan penambahan sari buah merah sebanyak 30 gram.

Dilihat dari nilai tingkat kesukaan aroma, nilai rata-rata terbesar yaitu pada formula es krim S20 dengan nilai rata-rata 2.48. Seperti pada penjelasan sebelumnya, dapat memberikan kesan buruk terhadap suatu produk.

Berdasarkan hasil uji statistik friedman terhadap frekuensi tingkat kesukaan warna formulasi es krim, diketahui sebanyak 14 $(56 \%)$ panelis sangat menyukai warna es krim pada sampel S20 dengan komposisi penambahan sari buah merah sebanyak 20

- Tingkat Kesukaan Rasa $\quad$ Tingkat Kesukaan Aroma $\quad$ Tingkat Kesukaan Warna $\quad$ Tingkat Kesukaan Tekstur

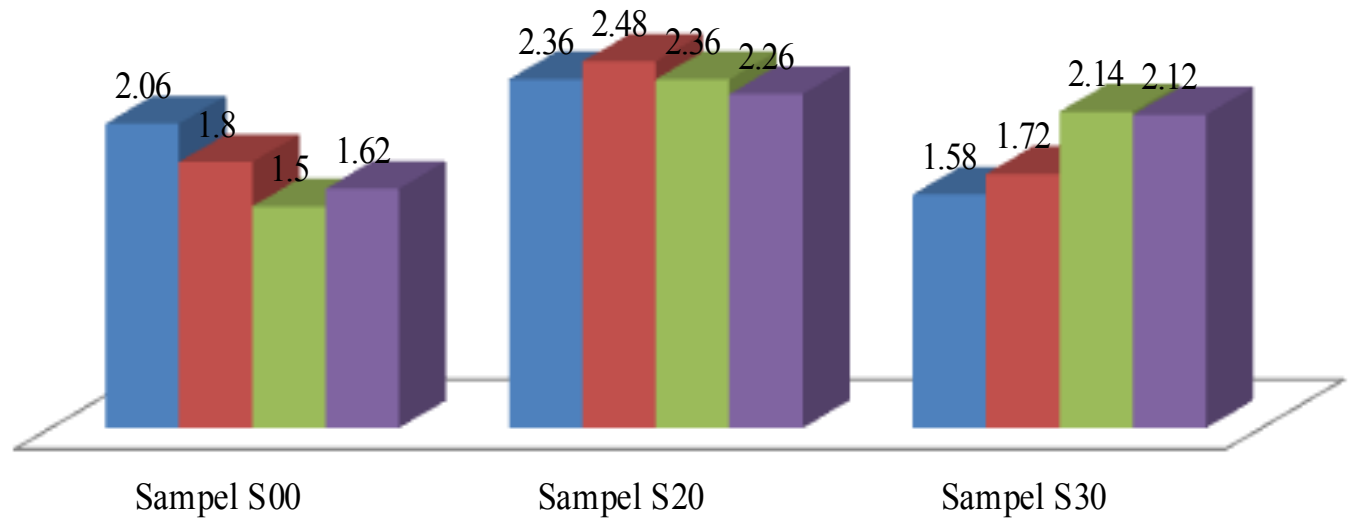

Gambar 1. Perbandingan Tingkat Kesukaan Es Krim Buah Merah Substitusi Tepung Sagu

Sumber: Data Primer, 2020

maka dapat diketahui bahwa penambahan sari buah merah yang berlebih dapat mempengaruhi tingkat kesukaan terhadap aroma dari formula es krim dikarenakan buah merah memiliki aroma yang khas (langu) yang agak sulit untuk dihilangkan.

Warna dapat menjadi salah satu faktor penentu konsumen untuk memilih suatu produk. Warna yang terlihat cerah dan segar diasumsikan sebagai produk yang memiliki kualitas yang baik. Sebaliknya, jika warna yang dihasilkan kusam, maka hal tersebut gram. Dan sebanyak $2(8 \%)$ panelis tidak menyukai warna es krim pada sampel S30 dengan penambahan sari buah merah sebanyak 30 gram.

Dilihat dari nilai tingkat kesukaan warna, nilai rata-rata terbesar yaitu pada formula es krim S20 dengan nilai rata-rata 2.36. Seperti pada penjelasan sebelumnya, maka dapat diketahui bahwa penambahan sari buah merah dapat meningkatkan nilai kesukaan terhadap warna dari formula es krim dikarenakan buah merah memiliki zat 
pewarna makanan alami yang tidak mengandung logam berat dan mikroorganisme berbahaya.

Tekstur merupakan salah satu faktor yang berperan penting sebagai penentu nilai kesukaan terhadap rasa dan kualitas dari suatu produk makanan. Tekstur dapat membuat rasa makanan menjadi enak maupun tidak, dikarenakan lidah manusia berperan sebagai pengecap yang juga dapat merasakan tekanan. Apabila tekstur dari sebuah makanan terasa aneh, maka akan terjadi penolakan dan penurunan nilai kesukaan, begitu pun sebaliknya.

Berdasarkan hasil uji statistik friedman terhadap frekuensi tingkat kesukaan tekstur formulasi es krim, diketahui sampel S20 dan S30 memiliki tekstur yang sangat disukai panelis yaitu sebanyak 9 (36\%) dengan komposisi penambahan sari buah merah masing-masing sebanyak 20 gram dan 30 gram. Dan sebanyak 1 (4\%) panelis tidak menyukai tekstur es krim pada sampel S00 dengan komposisi 0 gram sari buah merah.

Dilihat dari nilai tingkat kesukaan tekstur, nilai rata-rata terbesar yaitu pada formula es krim S20 dengan nilai rata-rata 2.26. Seperti pada penjelasan sebelumnya, maka dapat diketahui bahwa penambahan tepung sagu dan sari buah merah dapat meningkatkan nilai kesukaan terhadap tekstur dari formula es krim. Hal tersebut dikarenakan pati yang dimiliki oleh tepung sagu beserta zat lemak yang terdapat pada sari buah merah, sehingga dapat menghasilkan tekstur es krim ini menjadi lembut dan meminimalisir terjadinya pengkristalan adonan es.

Sejalan dengan hasil yang diperoleh, hasil penelitian yang dilakukan Wijayanti et al. (2017) yang menganalisis yoghurt yang ditambahkan konsentrasi tepung sagu ternyata memberikan perbedaan terhadap hasil rata-rata total padatan es krim yoghurt karena tepung sagu yang mengandung karbohidrat menjadi salah satu penyusun padatan dengan kadarnya sebesar $84,89 \%$, selain itu kerapatan pada molekulnya menyebabkan udara tidak dapat masuk sehingga es krim yoghurt yang dihasilkan memiliki tingkat kepadatan yang tinggi.

Sagu merupakan makanan yang rendah protein, vitamin dan mineral, kombinasinya dengan suplemen lain dapat menghasilkan nutrisi tinggi dan rasa. Dalam beberapa minggu saja konsumsi sagu dapat menambah berat badan orang yang menderita gangguan makan atau kekurangan nafsu makan karena tingginya kandungan kalori yang dimiliki. Sagu juga dapat memberikan energi yang cukup bagi orang yang mengalami kelelahan serta dapat menjadi suplemen bagi orang yang sakit (Verma \& Singh, 2017). 


\section{KESIMPULAN}

Daya terima terbaik diperoleh pada produk es krim buah merah substitusi tepung sagu dengan sampel S20 variasi (20:20). Terdapat perbedaan daya terima es krim dengan variasi substitusi tepung sagu dan buah merah. Penambahan aroma dan rasa yang berlebih dapat membuat mempengaruhi tingkat kesukaan panelis, hal ini dikarenakan buah merah memiliki aroma dan rasa yang has. Dengan substitusi sagu akan menghasilkan tekstur es krim ini menjadi lembut dan meminimalisir terjadinya pengkristalan adonan es. Penambahan sari buah merah dapat meningkatkan nilai kesukaan terhadap warna dari formula es krim dikarenakan buah merah memiliki zat pewarna makanan alami yang tidak mengandung logam berat dan mikroorganisme berbahaya.

\section{SARAN}

Untuk mendapatkan es krim buah merah substitusi tepung sagu dengan kualitas yang baik dan menarik, sebaiknya menggunakan 20 gram sari buah merah dan 20 gram tepung sagu. Kepada penelitian selanjutnya, diharapkan menggunakan sari buah merah yang diproduksi sendiri (tidak instan) agar hasil yang diperoleh lebih maksimal. Di samping itu, penelitian ini memerlukan kajian lebih dalam mengenai masa simpan produk.

\section{DAFTAR PUSTAKA}

Bullock, K., Lahne, J., \& Pope, L. (2020). Investigating the role of health halos and reactance in ice cream choice. Food Quality and Preference, 80, 103826. https:// doi.org/10.1016/ j.foodqual.2019.103826

Cruz, A. G., Antunes, A. E., Sousa, A. L. O., Faria, J. A., \& Saad, S. M. (2009). Ice-cream as a probiotic food carrier. Food Research International, 42(9), 1233-1239. https:// doi.org/10.1016/ j.foodres.2009.03.020

Damayanti, L., Evaangelina, I. A., Laviana, A., Herdiyati, Y., \& Kurnia, D. (2020). Antibacterial Activity of Buah Merah (Pandanus conoideus Lam.) Against Bacterial Oral Pathogen of Streptococcus sanguinis ATCC10556, Streptococcus mutans ATCC 25175, and Enterococcus faecalis ATCC 29212: An in Vitro Study. The Open Dentistry Journal, 14(1). http:// dx.doi.org/10.2174/18742106020140 113

Egharevba, H. O. (2019). Chemical Properties of Starch and Its Application in the Food Industry. In Chemical Properties of Starch. IntechOpen. http://doi.org/10.5772/ intechopen. 87777

Felle, Z. R., Wijayanti, M. A., \& Supargiyono, S. (2016). The effect of Pandanus conoideus Lamk extract to the serum level of TNF- $\alpha$, IL-10 and Parasitemia of Plasmodium berghei infected in mice. Tropical Medicine Journal, 3(1).

https://jurnal.ugm.ac.id/tropmed/artic le/view/5839

Hartatie, E. S. (2013). Kajian formulasi (bahan baku, bahan pemantap) dan 
metode pembuatan terhadap kualitas es krim. Jurnal Gamma, 7(1). http://202.52.52.22/index.php/gamm a/article/view/1415

Jamshidi, S., Beigrezaei, S., \& Faraji, H. (2018). A Review of Probable Effects of Antioxidants on DNA Damage. International Journal of Pharmaceutical and Phytopharmacological Research (eIJPPR), 8(5), 72-9. https:/eijppr.com/en/article/areview-of-probable-effects-ofantioxidants-on-dna-damage

Liestianty, D., Rodianawati, I., Patimah P., Muliadi, M. (2016). Chemical composition of modified and fortified sago starch (Metroxylonsp) from Northern Maluku. International Journal of Applied Chemistry, 12(3), 243-249. https://www.ripublication.com/ijac1 6/ijacv12n3_07.pdf

Manzoor, M. F., \& Ahmed, N. (2017). Extraction and utilization of Manihot esculenta crantz and Trapanatans starch as a stabilizer in soy milk based ice cream preparation. Agricultural Research and Technology, 8(2), 001-005. http://dx.doi.org/10.19080/ARTOAJ .2017.08.555733

Metaragakusuma, A. P., Katsuya, O., \& Bai, H. (2016). An Overview of the Traditional use of sago for Sagobased Food Industry in Indonesia. KnE Life Sciences, 119-124. https://doi.org/10.18502/kls.v3i3.38 2

Nuringtyas, T. R., Pratama, Y., Galih, G., Wahyuono, S., \& Moeljopawiro, S. (2014). Cytotoxicity of Buah Merah (Pandanus conoideus Lamk.) Extract on Breast Cancer Cell Line (T47D). Indonesian Journal of Biotechnology, 19(1), $71-78$ https://doi.org/10.22146/ijbiotech.86 36

Nzamwita, M., Duodu, K. G., \& Minnaar, A. (2017). Stability of $\beta$-carotene during baking of orange-fleshed sweet potato-wheat composite bread and estimated contribution to vitamin A requirements. Food chemistry, 228, 85-90. https://doi.org/10.1016/j.foodchem.2 017.01 .133

Popkov, V. A., Fetisova, A. N., Nesterova, O. V., \& Samylina, I. A. (2001). Experience in using phytopreparations to prevent and correct inflammatory urinary tract diseases. Vestnik Rossiiskoi akademii meditsinskikh nauk, (2), 11-13. https://europepmc.org/article/med/1 1338496

Putri, R. (2015). Pengaruh Jumlah dan Bentuk Sagu (Metroxylon sp) terhadap Hasil jadi Es krim. Jurnal Tata Boga, 4(3). https://jurnalmahasiswa.unesa.ac.id/ index.php/jurnal-tataboga/article/view/13210

Ridawati, R., \& Alsuhendra, A. (2015). Pelatihan Pembuatan Es Krim Sehat Untuk Balita Bagi Kader Posyandu Di Kelurahan Duren Sawit Jakarta Timur. Sarwahita, 12(2), 121-130. https://doi.org/10.21009/sarwahita.1 22.08

Roreng, M. K., Palupi, N. S., \& Prangdimurti, E. (2014). Carotenoids from red fruit (Pandanus conoideus Lam.) extract are bioavailable: a study in rats. IOSR Journal Of Pharmacy, 4, 11-16. http://dx.doi.org/10.9790/3013040203011-16

Sandhiutami, N. M. D., \& Indrayani, A. W. (2012). Antioxidant Activity Test 
and Determination of Phenolic and Flavonoid Contents from Pandanus conoideus Lam. Jurnal Ilmu Kefarmasian Indonesia, 10(1), 1319.

http://jifi.farmasi.univpancasila.ac.id/ index.php/jifi/article/view/271

Sarungallo, Z. L., Hariyadi, P., Andarwulan, N., Purnomo, E. H., \& Wada, M. (2015). Analysis of $\alpha$-cryptoxanthin, $\beta$-cryptoxanthin, $\alpha$-carotene, and $\beta$ carotene of Pandanus conoideus oil by high-performance liquid chromatography (HPLC). Procedia Food Science, 3, 231-243. https://dx.doi.org/10.1016/j.profoo.2 015.01 .026

Sarungallo, Z. L., Roreng, M. K., \& Santoso, B. (2019). Chemical properties, carotenoid, tocopherol and fatty acid composition of three clones of red fruit (Pandanus conoideus Lam.) oil of different ripening stages. International Food Research Journal, 26(2).

http://www.ifrj.upm.edu.my/26\%20( 02)\%202019/(31).pdf

Schirra, C., Xia, N., Schüffler, A., Heck, A., Hasselwander, S., Förstermann, U., \& Li, H. (2020). Phosphorylation and activation of endothelial nitric oxide synthase by red fruit (Pandanus conoideus Lam) oil and its fractions. Journal of Ethnopharmacology, 251, 112534. https://doi.org/10.1016/j.jep.2019.11 2534

Sugiritama, I. W., Ratnayanti, I. D., Wiryawan, I. S., Wahyuniari, I. I., Linawati, N. M., \& Arijana, I. G. K. N. (2016). Effect of Red Fruit Oil (Pandanus Conoideus Lam) on Animal Model of Preeclampsia. International Journal of Science and Research (IJSR), 5(7), 17701773. https://www.ijsr.net/get_abstract.php ?paper_id=ART2016604

Sumarsono, P., \& Susilowati, S. (2016). Red fruit oil increases trophoblast cell and decreases caspase-9 expression in placenta of lead exposed mice. Universa Medicina, 35(2), 110-118. http://dx.doi.org/10.18051/UnivMed. 2016.v35.110-118

Tang'nga, G. A. (2019). Antioxidant Activities Of Soy Yoghurt Product In Combination With Red Fruit (Pandanus Conoideus Lam.). Journal of Food and Life Sciences, 3(2), 6573.

https://jfls.ub.ac.id/index.php/jfls/arti cle/view/95

Tewari, S., David, J., \& Gautam, A. (2019). A review on probiotic dairy products and digestive health. J. Pharmacogn. Phytochem, 8, 368-372. http://www.phytojournal.com/archiv es $/$ ?year $=2019 \&$ vol $=8 \&$ issue $=3 \&$ Art icleId $=8112 \&$ si $=$ false

Verma, V. K., \& Singh, S. S. (2017). Preparation of ice cream blended with Cocoa and Sago powder. The Pharma Innovation, 6(9), 5-8. http://www.thepharmajournal.com/ar chives/2017/vol6issue9/PartA/6-850-388.pdf

Wabula, R. A., Dali, S., \& Widiastuti, H. (2019). Aktivitas Antioksidan Ekstrak Etanol Buah Merah (Pandanus conoideus Lam.) dengan Metode FRAP. Window of Health: Jurnal Kesehatan, 329-337. https://doi.org/10.33368/woh.v0i0.20 3

Wijayanti, I. A., Purwadi, P., \& Thohari, I. (2017). Pengaruh Penambahan Tepung Sagu pada Yoghurt terhadap Sifat Fisik Es Krim Yoghurt. Jurnal 
Ilmu dan Teknologi Hasil Ternak (JITEK), 11(1), 38-45. https://doi.org/10.21776/ub.jitek.201 6.011 .01 .4

Witono, J. R., Noordergraaf, I., Heeres, H. J., \& Janssen, L. P. B. M. (2014). Water absorption, retention and the swelling characteristics of cassava starch grafted with polyacrylic ac- id. Carbohydrate polymers, 103, 325-332.

https://doi.org/10.1016/j.carbpol.201 3.12 .056

Zulaikhah, S. T. (2017). The role of antioxidant to prevent free radicals in the body. Sains Medika, 8(1), 39-45. http://dx.doi.org/10.26532/sainsmed .v8i1.1012 